\title{
PERAN LATIHAN DISUPERVISI PADA PASIEN DENGAN PENYAKIT ARTERI PERIFER EKSREMITAS BAWAH
}

\author{
Eka Fithra Elfi
}

\begin{abstract}
Abstrak
Penyakit arteri perifer (peripheral arterial disease, $P A D$ ) merupakan kumpulan kelainan yang menghambat aliran darah ke ekstremitas, pada umumnya terjadi akibat aterosklerosis dan bermanifestasi sebagai klaudikasio. Disamping terapi medikamentosa dan endovaskuler yang optimal, manajemen non farmakologi PAD terbukti efektif mengurangi gejala, meningkatkan kemampuan berjalan dan kualitas hidup. Telah dilaporkan laki-laki usia 58 tahun penderita klaudikasio intermitten karena oklusi arteri iliaka komunis sinistra. Pasien masih merasakan gejala setelah terapi medikamentosa dan angioplasty tranluminal percutaneous. Setelah dilakukan program latihan disupervisi, gejala, kemampuan berjalan, dan indeks brachial ankle meningkat signifikan. Program latihan disupervisi pada pasien PAD dinilai penting sebagai terapi primer untuk meningkatkan kapasitas fungsional dan kualitas hidup untuk manajemen jangka panjang.
\end{abstract}

Kata Kunci: penyakit arteri perifer, klaudikasio intermiten, rehabilitasi, latihan olahraga disupervisi

\begin{abstract}
Peripheral arterial disease (PAD) is a disorder that obstruct the arterial blood supply to extremities, most commonly caused by atherosclerosis and manifests as claudicatio. Aside from optimal medical therapy and endovascular therapy, non pharmacological managements of PAD are proven effectively improving symptoms, increasing walking distance, and overall quality of life. The case report describe a 58 years old male with known claudicatio intermitten due to occlusion of left communis iliac artery. After medical therapy and percutaneous transluminal angioplasty, the patient still symptomatic. After supervised exercise training was prescribed to the patient, the symptom, walking distance, and ankle brachial index was improved significantly. Rehabilitation in PAD with supervised exercise training plays significant role as primary therapy in patients with PAD to improve functional capacity and quality of life in long term management.
\end{abstract}

Keywords: peripheral arterial disease, claudicatio intermitten, rehabilitation, supervised exercise training

Afiliasi Penulis : Bagian Kardiologi dan Vaskuler RSUP M. Djamil Padang/ Fakultas Kedokteran Universitas Andalas Padang Korespondensi: ekafithra@yahoo.com 


\section{PENDAHULUAN}

Penyakit arteri perifer (peripheral arterial disease/ $P A D$ ) secara umum merupakan kumpulan kelainan yang menghambat aliran darah ke ekstremitas baik atas maupun bawah, kebanyakan terjadi akibat aterosklerosis. Gejala utama dari $P A D$ ekstremitas bawah, klaudikasio intermiten, cenderung menghambat aktivitas pasien, menimbulkan ketergantungan terhadap orang lain, dan menurunkan kualitas hidup pasien tersebut. ${ }^{1}$ Prevalensinya bervariasi tergantung umur, namun jumlahnya lebih tinggi pada kelompok usia diatas 40 tahun (15\%-20\%) Kebanyakan pasien PAD $(80 \%)$, adalah perokok maupun bekas perokok. ${ }^{2} \mathrm{Di}$ Indonesia, prevalensinya pada pasien diabetes mellitus mencapai 44\%. ${ }^{3}$ Data rekam medis Pusat Jantung Harapan Kita (PJNHK) menunjukkan jumlah pasien $P A D$ ekstremitas bawah sebanyak 119 pasien selama Januari 2011 hingga Agustus 2012. ${ }^{4}$

Manajemen $P A D$ ekstremitas bawah yang direkomendasikan saat ini terdiri atas terapi medikamentosa optimal (termasuk faktor resiko), latihan disupervisi, dan revaskularisasi endovaskular. Ketiga manajemen ini terbukti efektif dalam mengurangi gejala klaudikasio, meningkatkan jarak berjalan, dan memperbaiki kualitas hidup. ${ }^{5}$ Salah satu penelitian terbaru, CLEVER, menunjukkan bahwa latihan disupervisi dapat meningkatkan jarak berjalan maksimal (hingga $200 \%$ dibanding sebelum latihan), sementara angioplasti disertai pemasangan stent meningkatkan kualitas $\mathrm{h}$ idup secara keseluruhan. ${ }^{6}$ Studi-studi lain juga memperlihatkan peran latihan disupervisi dalam mengurangi gejala klaudikasio melalui berbagai mekanisme, seperti meningkatkan jumlah kolateral, fungsi endotel, ambilan oksigen oleh otot, kapasitas oksidasi otot betis, serta menekan faktor inflamasi dan faktor resiko kardiovaskular secara umum. ${ }^{7}$ Saat ini latihan dibawah pengawasan merupakan rekomendasi kelas IA untuk manajemen awal klaudikasio. ${ }^{8}$

Presentasi kasus ini bertujuan untuk membahas peran latihan disupervisi pada pasien dengan penyakit arteri perifer ekstremitas bawah.

\section{LAPORAN KASUS}

Seorang pasien laki-laki 58 tahun dirujuk ke bagian prevensi dan rehabilitasi PJNHK dengan keluhan utama nyeri pada tungkai kanan jika berjalan jauh. Keluhan nyeri terutama dirasakan pada tungkai bawah kanan muncul bila berjalan agak cepat dan jauh (lebih dari 200 meter) dan berkurang dengan istirahat. Keluhan tersebut telah dirasakan sejak 1 tahun yang lalu. Faktor resiko pasien adalah hipertensi terkontrol dengan obat sejak 1 tahun yang lalu, serta merokok 1 bungkus perhari. Pasien juga dikenal dengan penyakit asma bronkial dan mengkonsumsi medikasi inhalasi Terbuhaler bila timbul gejala asma.

Riwayat penyakit pasien dimulai pada tanggal 5 November 2011, dimana pasien masuk perawatan PJNHK dengan keluhan utama kebas pada tungkai kiri. Sebelumnya pasien menjalani perawatan selama dua minggu di RS Medan dengan infark miokard elevasi segmen ST anteroseptal. Pasien kemudian didiagnosis dengan iskemia tungkai akut derajat I karena saddle emboly infra renal dan dilakukan thrombosuction dengan Angiojet. Pasca 
perawatan trombus kembali timbul sehingga pasien mendapat tambahan antikoagulan. Pada pemeriksaan lebih lanjut ditemukan stenosis nonsignifikan pada arteri koroner $L A D$ (left anterior descenden) dan RCA (right coronary artery), serta total oklusi pada arteri iliakakomunis kiri, sehingga prosedur dilanjutkan dengan percutaneous transluminal angioplasty (PTA) dan pemasangan stent Sinus-Superflux 535 9.0$60 \mathrm{~mm}$ pada arteri iliaka komunis kiri pada tanggal 5 Januari 2012. Sejak itu pasien melaporkan keluhan kebas pada kaki kiri berkurang jauh dan pasien mendapat terapi rutin Aspilet 1x80 mg, clopidogrel $1 \times 75 \mathrm{mg}$, telmisartan $1 \times 80$ $\mathrm{mg}$, simvastatin $1 \times 20 \mathrm{mg}$, carvedilol 1x6,25 mg, dan warfarin 1x2 mg.

Pada pemeriksaan fisik ditemukan keadaan umum baik, tekanan darah lengan kanan 117/66 mmHg, lengan kiri $115 / 70 \mathrm{mmHg}$ frekuensi nadi $75 \mathrm{x} /$ menit, frekuensi nafas 16-18x/menit. Pasien tidak tampak anemis maupun ikterik. Pemeriksaan jantung menunjukkan ukuran jantung normal, bunyi jantung reguler tanpa bising dan gallop, sementara pada paru didapatkan suara nafas vesikuler, tanpa ronki dan wheezing. Pada pemeriksaan ekstremitas, akral hangat, tidak tampak edema, tekanan darah di tungkai kanan 106/60 mmHg, tungkai kiri 116/70 $\mathrm{mmHg}$. Pulsasi arteri femoralis, arteri poplitea, dan arteri dorsalis pedis kanan dan kiri dapat diraba.

Elektrokardiogram (gambar 1) menunjukkan irama sinus, frekuensi QRS $78 \mathrm{x} /$ menit, axis normal, $P$ wave normal, interval PR $160 \mathrm{~ms}$, durasi QRS $8 \mathrm{~ms}$, ditemukan gambaran poor $\mathrm{R}$ di V1-V5, tidak ditemukan perubahan segmen ST. Foto torak (gambar 2) memperlihatkan ukuran siluet jantung dalam batas normal dengan cardiothoracic index (CTR) $45 \%$, tidak tampak gambaran kongesti maupun infiltrat. Pemeriksaan ekokardiografi memperlihatkan dimensi ruang jantung dalam batas normal dengan end diastolic diameter ventrikel kiri (LVEDD) $47 \mathrm{~mm}$, end systolic diameter (LVESD) $32 \mathrm{~mm}$, fungsi ventrikel kiri dan kanan baik denganleft ventricle ejection fraction(LVEF) $59 \%$ dan TAPSE $2.0 \mathrm{~cm}$, ditemukan hipokinetik segmental di dinding anteroseptal, serta fungsi diastolik dan katupkatup dalam keadaan baik.

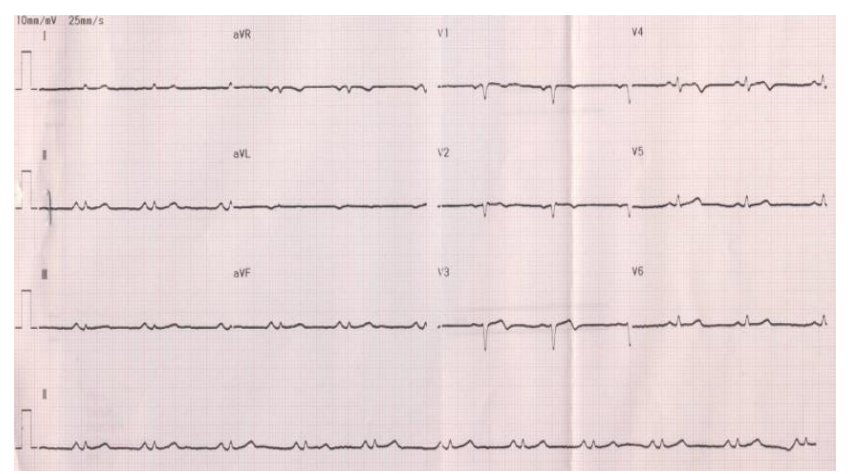

Gambar 1. Elektrokardiogram

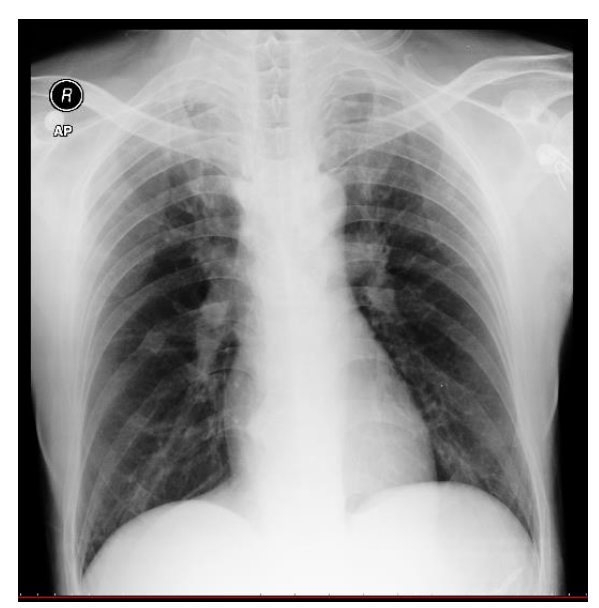

Gambar 2. Foto torak

Pemeriksaan invasif berupa angiografi koroner pada 13 Desember 2011 memperlihatkan stenosis nonsignifikan (50\%) di $R C A$ dan stenosis ireguler di proksimal $L A D$. Pada ekstremitas kiri ditemukan gambaran aliran normal di 
ekstremitas kanan, sementara ditemukan total oklusi pangkal arteri iliaka komunis kiri, dan telah dilakukan PTA dengan pemasangan stent pada arteri tersebut.
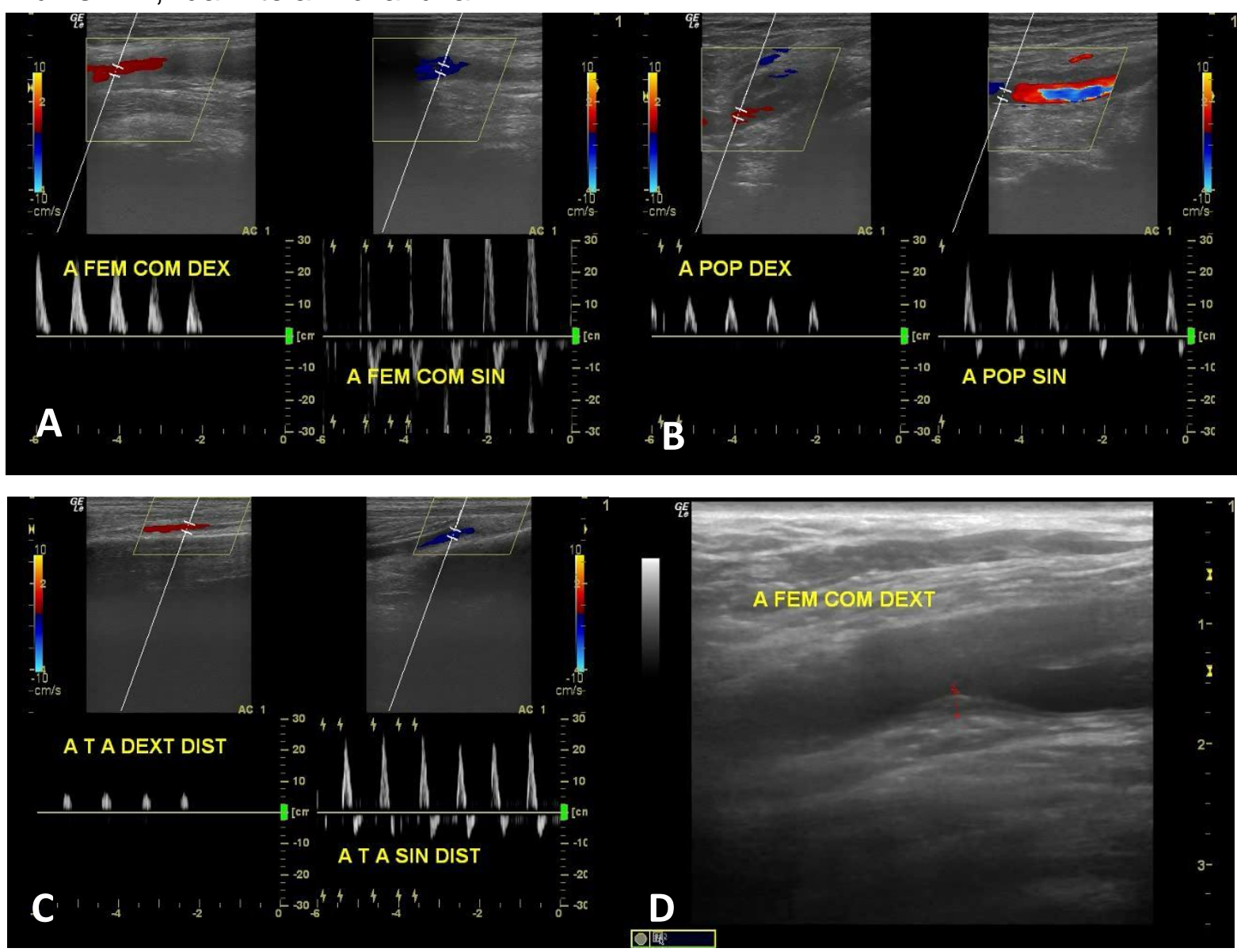

Gambar 3. Doppler vaskuler pada: A. arteri femoralis komunis, B. arteri poplitea, C. arteri tibialis anterior, dan D. plak pada arteri femoralis komunis dextra

Pemeriksaan non invasif vaskuler evaluasi (gambar 3) menunjukkan terdapat oklusi pada arteri tibialis posterior 1/3 distal tungkai kiri dengan masih ditemukan aliran arteri hingga distal. Pada tungkai kanan ditemukan stenosis $70 \%-80 \%$ pada arteri iliaka komunis kanan dengan aliran arteri yang masih baik hingga distal. Analisis reografi doppler menunjukkan adanya klaudiokasio pada tungkai kanan dengan nilai ABI (Ankle Brachial Index) 0,83 dan aliran arteri yang normal pada tungkai kiri dengan $A B I 0,94$ (gambar 4). 
Berdasarkan klinis dan pemeriksaan penunjang, pasien didiagnosis sebagai Iskemia tungkai kronik (chronic limb ischemia, CLI) dengan klaudikasio intermiten pada tungkai kiri. Terapi farmakologis tetap rutin diberikan seperti yang disebutkan sebelumnya.

Pasien kemudian dikirim ke bagian prevensi dan rehabilitasi untuk menjalankan rehabilitasi $P A D$. Sesuai dengan protokol dari penelitian CLEVER, pasien menjalani tes jalan 6 menit untuk nilai awal dan dilanjutkan dengan pemanasan. Program latihan dimulai dengan jalan biasa di treadmill atau di lintasan dengan kecepatan $3.2 \mathrm{~km} / \mathrm{jam}$ selama 30 menit hingga timbul nyeri ringan-sedang (skor klaudikasio 3-4). Jika timbul nyeri tersebut, pasien diminta untuk beristirahat, setelah nyeri hilang (skor klaudikasio 1), pasien diminta untuk berjalan kembali. Pola berjalan intermiten tersebut dilakukan selama 30 menit. Pada setiap sesi, intensitas ditingkatkan baik dari kecepatan, tinggi treadmill, dan durasi, hingga maksimal 50 menit dengan kecepatan maksimal $4,8 \mathrm{~km} / \mathrm{jam}$ dan elevasi $15 \%$, atau sesuai toleransi maksimal dari pasien (tabel 1).

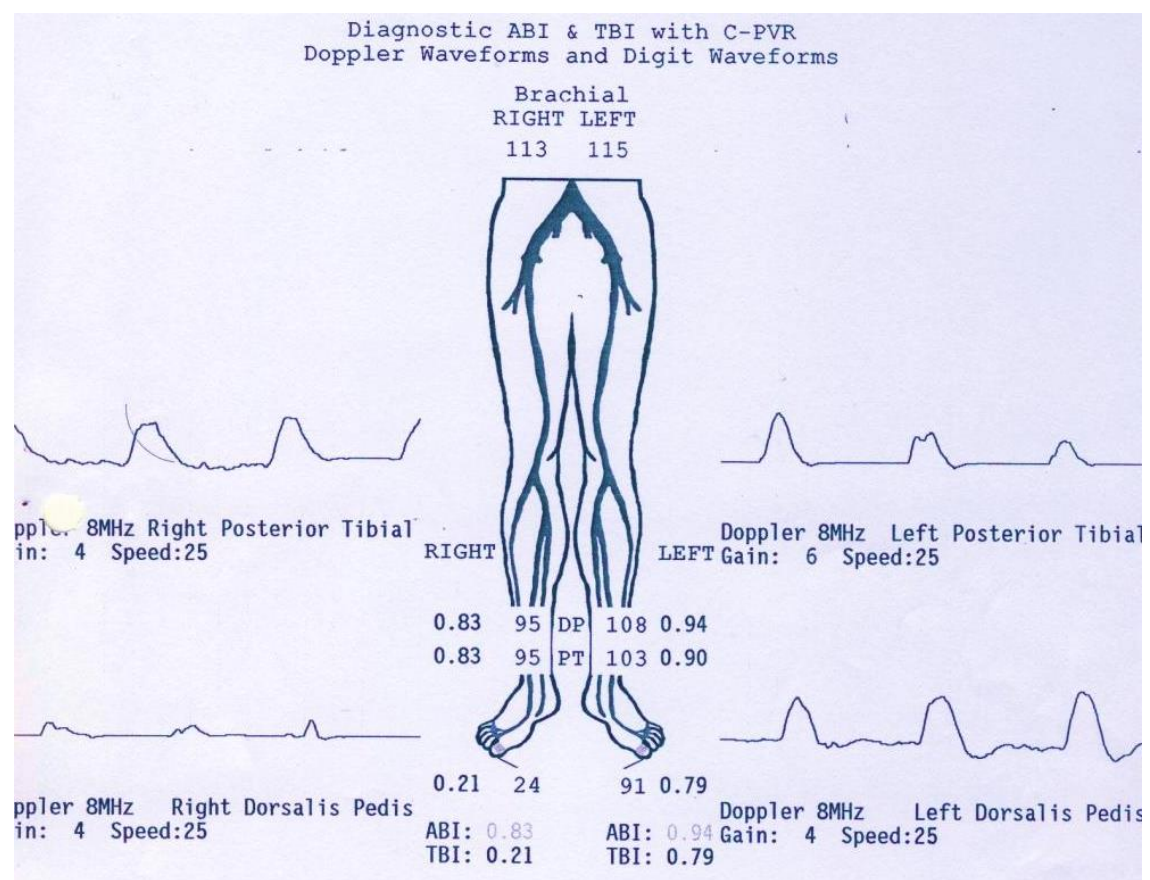

Gambar 4. ABI sebelum program latihan pada pasien

Tabel 1. Profil latihan disupervisi pada pasien

\begin{tabular}{lccccc}
\hline Profil & 6MWT & Sesi I & Sesi II & Sesi III & Sesi IV \\
\hline Jarak berjalan & $200 \mathrm{~m}$ & $1,5 \mathrm{~km}$ & $1,7 \mathrm{~km}$ & $1,9 \mathrm{~km}$ & $2,2 \mathrm{~km}$ \\
Kecepatan & & $3,6 \mathrm{~km} / \mathrm{jam}$ & $3,8 \mathrm{~km} / \mathrm{jam}$ & $4,0 \mathrm{~km} / \mathrm{jam}$ & $4,1 \mathrm{~km} / \mathrm{jam}$ \\
Onset bebas nyeri & - & 30 menit & 30 menit & 30 menit & 30 menit \\
ABI & 0,83 & 0,80 & 0,85 & 0,90 & 0,96 \\
\hline
\end{tabular}

Pada pasien ini sesi rehabilitasi hanya dapat dijalankan sebanyak 4 kali.
Intensitas dapat ditingkatkan bertahap, namun durasi tidak bisa ditingkatkan 
karena timbul gejala asma bronkial. Hingga sesi terakhir, pasien mampu berjalan di treadmill dengan kecepatan 4,1 km/jam selama 30 menit nonstop tanpa mengeluhkan nyeri. Sesi latihan kemudian dilanjutkan di kota asal pasien, Medan. Ditemukan peningkatan $A B I$ tungkai kiri selama program, dari 0,83 sebagai nilai acuan istirahat, hingga $A B I$ 1,1 pasca latihan sesi ke-4. Dalam evaluasi lebih lanjut, pasien melaporkan mampu berjalan dengan kecepatan 4,1 $\mathrm{km} / \mathrm{jam}$ selama 40 menit nonstop tanpa timbul nyeri. Berdasarkan hasil evaluasi ter-sebut, pasien dianjurkan untuk terus melakukan program latihan secara rutin disertai dengan farmakoterapi dan pengaturan pola hidup yang optimal.

\section{PEMBAHASAN}

\section{Manajemen Klaudikasio Intermiten}

Klaudikasio didefinisikan sebagai rasa tidak nyaman pada otot tungkai bawah akibat aktifitas atau olahraga dan berkurang dengan istirahat, disertai dengan kelelahan otot, nyeri, atau kram. ${ }^{1}$ Klaudikasio merupakan gejala yang ditemukan pada sepertiga pasien dengan penyakit arteri perifer ekstremitas bawah. Keluhan tersebut membatasi kemampuan berjalan dan aktifitas fisik pasien, dan dengan sendirinya menurunkan kualitas hidup pasien.

$P A D$ yang mendasari klaudikasio umumnya merupakan manifestasi dari proses aterosklerosis pada dinding arteri. Prevalensinya meningkat sesuai dengan umur dan kontribusi dari faktor resiko kardiovaskular lainnya. Merokok dan diabetes merupakan faktor resiko utama kejadian aterosklerosis pada $P A D$, dan faktor resiko lain mencakup hipertensi, jenis kelamin laki-laki, umur tua, hiperlipidemia, obesitas, serta kurangnya aktifitas fisik turut meningkatkan resiko penyakit tersebut. 8,9

Secara klinis klaudikasio dapat didiagnosis dengan anamnesis keluhan rasa tidak nyaman, kram, nyeri otot, terutama pada otot betis, paha, kaki, dan pinggul yang timbul saat aktifitas atau olahraga dan berkurang dengan istirahat. Peningkatan jarak berjalan turut berkontribusi terhadap munculnya gejala tersebut. Adanya faktor resiko aterosklerosis, terutama merokok dan diabetes melitus memperkuat kecurigaan suatu iskemia tungkai kronik. Pemeriksaan noninvasif $\mathrm{ABI}$ merupakan penilaian yang direkomendasikan untuk skrining dan diagnosis, dimana $\mathrm{ABI} \leq 0,9$ menunjukkaan adanya suatu $P A D$. Pengukuran $A B I$ dapat dilakukan baik pada saat istirahat maupun setelah olahraga. Pemeriksaan penunjang lainnya seperti duplex ultrasound, computed tomography angiography, dan magnetic resonance angiography, termasuk baku emasnya, angiografi invasif, terutama berperan pada kasus yang tidak dapat dinilai dengan $A B I$, serta jika revaskularisasi merupakan pilihan terapi. ${ }^{2,5,8}$

Rekomendasi dari European Society of Cardiology (ESC) dan American College of Cardiology and The American Heart Association (ACC/AHA) untuk pengobatan klaudikasio meliputi beberapa elemen, yaitu farmakoterapi, revaskularisasi, dan rehabilitasi olahraga serta pengendalian faktor resiko. Faktor resiko kardiovaskuler harus ditekan, baik melalui pola hidup, maupun dengan bantuan medikamentosa. Program latihan olahraga, khususnya dibawah pengawasan, merupakan terapi lini pertama pada pasien klaudikasio. Perannya terutama un- 
tuk mengurangi gejala dan meningkatkan jarak berjalan. Farmakoterapi berupa antiplatelet, vasodilator, antihipertensi, maupun golongan statin memperlihatkan efek yang baik untuk meningkatkan jarak berjalan pada pasien klaudikasio. Antiplatelet dan antikoagulan juga direkomendasikan pada pasien yang telah menjalani revaskularisasi untuk meningkatkan patensi hasil tindakan. ${ }^{10} \mathrm{Re}$ vaskularisasi, baik secara endovaskuler maupun secara bedah, direkomendasikan pada pasien-pasien dengan klaudikasio sedang hingga berat, serta tergantung pada jenis lesi, komorbiditas, fasilitas, serta pilihan pasien sendiri. ${ }^{2,5,8}$

\section{Peran Latihan Olahraga pada Klaudikasio}

Panduan dari ACC/AHAdan ESC mengenai manajemen klaudikasio, latihan olahraga yang disupervisi merupakan rekomendasi kelas IA sebagai terapi awal klaudikasio. Pasien-pasien dengan klaudikasio yang menjalani latihan olahraga yang disupervisi mampu mencapai jarak berjalan tanpa nyeri serta jarak berjalan maksimum dua kali lipat lebih baik dibanding tanpa latihan. Peningkatan kapasitas fungsional tersebut meningkat secara bertahap dan tampak jelas pada minggu ke-4, serta meningkat secara progresif setelah 12 minggu. $2,8,11$

Parameter keberhasilan program latihan klaudikasio diukur berdasarkan jarak berjalan tanpa nyeri, jarak berjalan maksimal, dan pengukuran kualitas hidup. Suatu studi literatur dari database Cochrane memperlihatkan bahwa program latihan diatas dua sesi perminggu selama 3-12 bulan menunjukkan peningkatan kemampuan berjalan secara keseluruhan antara $50 \%$ sampai $200 \%$. Meta analisis dari 21 uji random dan nonrandom menunjukkan peningkatan $179 \%$ jarak berjalan bebas nyeri dan 122\% jarak tempuh maksimal pada pasien klaudikasio yang menjalani latihan fisik. ${ }^{12,13}$ Peningkatan ini tidak hanya ditemukan pada pasien simptomatis, namun juga pada pasien $P A D$ asimptomatis. ${ }^{14}$

Perbandingan antara terapi medikamentosa optimal, program latihan, serta revaskularisasi untuk pasien klaudikasio telah banyak dilaporkan dalam bentuk uji klinis dan meta analisis. Meta analisis penelitian sepanjang 19802003 memperlihatkan peningkatan kapasitas fungsional yang lebih bermakna pada pasien yang menjalani angioplasti, sementara kualitas hidup secara keseluruhan meningkat baik pada grup yang menjalani angioplasti maupun grup latihan olahraga. ${ }^{15}$ Hasil serupa juga ditemukan pada uji klinis random tahun 2009, dimana peningkatan setelah 6-12 bulan sebanding antara program latihan disupervisi dengan revaskularisasi, namun efek segera tampak pada pasien pasca revaskularisasi. ${ }^{16}$ Penelitian terbaru, CLEVER (CLaudication: Exercise Versus Endoluminal Revascularization), yang membandingkan antara farmakoterapi optimal, latihan disupervisi, dan revaskulariasi endovaskuler memperlihatkan superioritas baik program latihan maupun revaskularisasi terhadap farmakoterapi, dengan peningkatan bermakna terhadap kemampuan berjalan pada grup yang menjalani latihan, serta dengan perbaikan kualitas hidup secara umum yang lebih baik pada grup yang menjalani revaskularisasi. ${ }^{6}$ Secara umum dapat digambarkan bahwa baik program latihan maupun revaskularisasi dapat meningkatkan kapasitas 
fungsional dan memperbaiki kualitas hidup untuk pasien-pasien PAD.

Mekanisme fisiologis latihan terhadap perbaikan gejala klaudikasio belum sepenuhnya dimengerti, namun beberapa penelitian menunjukkan kemungkinan efek yang ditimbulkan ditunjukkan oleh gambar 5 dan dijabarkan sebagai berikut:9, 17,18,19,20

1. Meningkatnya efisiensi konsumsi oksigen oleh jaringan otot karena modifikasi pola berjalan sehingga dibutuhkan energi yang lebih sedikit.

2. Meningkatnya kemampuan metabolisme otot: meningkatnya kapasitas enzim oksidatif, berkurangnya kadar acylcarnitine.

3. Meningkatnya daya tahan dan kekuatan otot

4. Berkurangnya persepsi nyeri

5. Perbaikan fungsi endotel

6. Peningkatan kolateral

7. Berkurangnya viskositas darah

8. Berkurangnya faktor inflamasi siste-mik

9. Memperbaiki faktor kardiovaskuler lainnya: berkurangnya tekanan darah, resistensi insulin, faktor inflamasi (hsCRP), depresi dan stres psikososial, obesitas, serta perbaikan pada fungsi otonom, reologi darah, dan profil lipid.

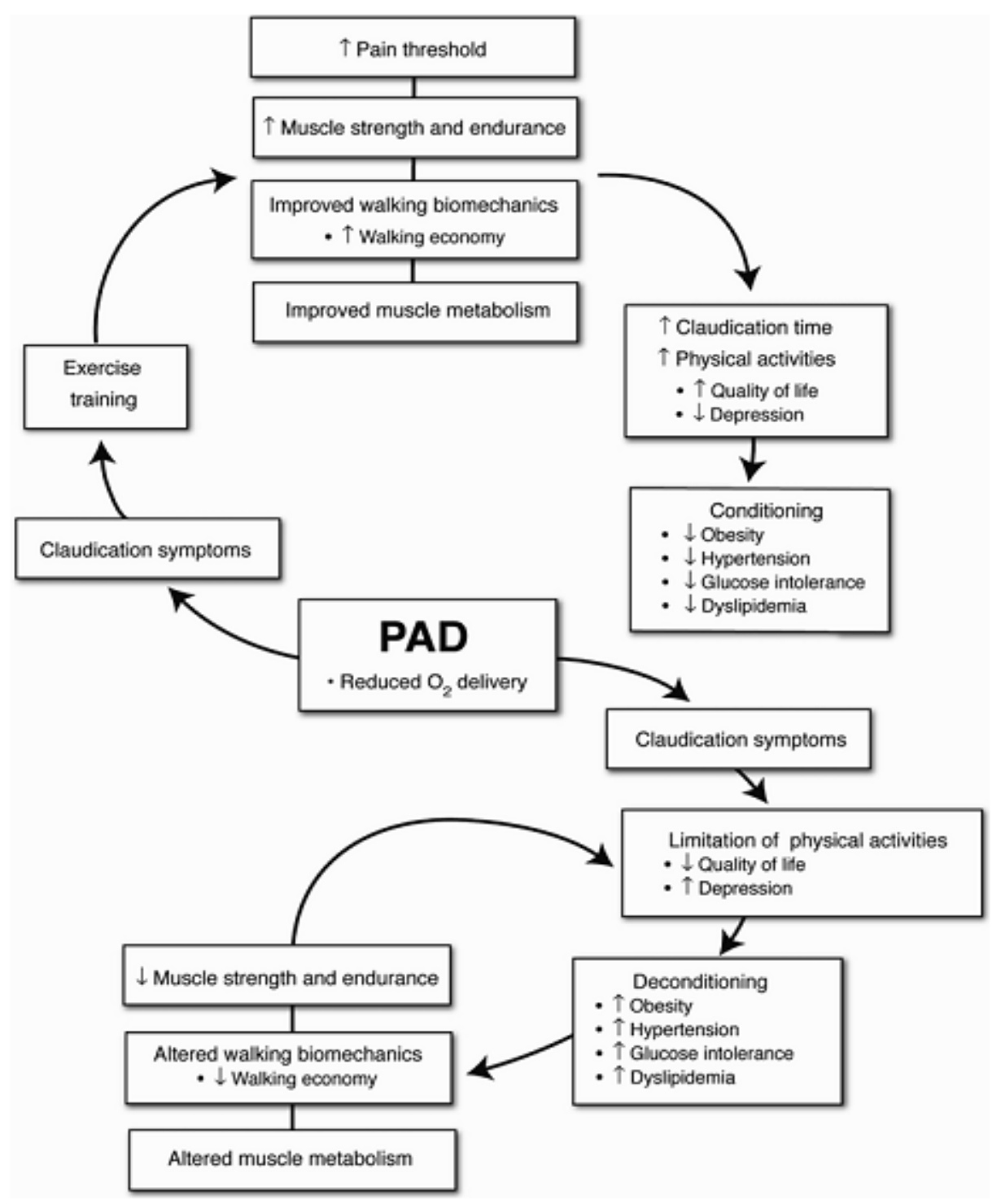

Gambar 5. Mekanisme peran latihan pada pasien $P A D$ dengan klaudikasio ${ }^{9}$ 
Program latihan menggunakan treadmill atau lintasan untuk pasien dengan klaudikasiotercantum pada tabel 2. ${ }^{21}$ Program latihan terdiri atas 3-5 sesi per minggu selama 12-24 minggu. Latihan dijalankan dibawah pengawasan dengan pengukuran objektif terhadap keluhan klaudikasio, jarak dan lama berjalan maksimal, serta tanda-tanda iske- mia miokard. Pengukuran tekanan darah, denyut nadi, dan elektrokardiogram 12 lead sebaiknya dilakukan selama latihan. Target program adalah peningkatan jarak tempuh maksimal dan jarak berjalan tanpa nyeri.Setelah program yang disupervisi selesai, progam latihan dilanjutkan dirumah dengan pola yang sama.

Tabel 2. Program latihan $P A D$ (3 sesi/minggu, 12-24 minggu)

\begin{tabular}{|c|c|}
\hline \multirow{6}{*}{$\begin{array}{l}\text { Fase } \\
\text { awal }\end{array}$} & Beban kerja awal (sesuai uji Treadmill) \\
\hline & Pemanasan 5 menit \\
\hline & Dimulai 3.2 km/jam (Treadmill) \\
\hline & $\begin{array}{l}\text { Dihentikan bila skala klaudikasio 4-5 (dalam } 5 \text { menit), dan pasien istirahat } \\
\text { (duduk) }\end{array}$ \\
\hline & Dilanjutkan kembali setelah skala klaudikasio 1 \\
\hline & $\begin{array}{l}\text { Latihan dilakukan selama 15-30 menit (intermitten) } \\
\text { Pendinginan } 5 \text { menit }\end{array}$ \\
\hline \multirow{5}{*}{$\begin{array}{l}\text { Fase } \\
\text { lanjutan }\end{array}$} & Pada sesi berikutnya, lama berjalan ditingkatkan 5 menit pada setiap sesi \\
\hline & sehingga total waktu latihan mencapai 50 menit \\
\hline & Tahap 2 : ditingkatkan kecepatan $0,3 \mathrm{~km} / \mathrm{jam}$ sampai $4,8 \mathrm{~km} / \mathrm{jam}$ \\
\hline & Tahap 3 : ditingkatkan elevasi $12 \%, 14 \%$, dan $15 \%$ \\
\hline & Tahap 4 : ditingkatkan kecepatan $0.3 \mathrm{~km} / \mathrm{jam}$ sesuai toleransi pasien \\
\hline $\begin{array}{l}\text { Aktivitas } \\
\text { harian }\end{array}$ & Jalan di rumah 30-60 menit minimal 2 kali per minggu \\
\hline \multicolumn{2}{|c|}{$\begin{array}{l}\text { Skala klaudikasio: } 1=\text { tidak ada nyeri; } 2=\text { onset klaudikasio; } 3=\text { nyeri ringan; } 4=\text { nyeri } \\
\text { sedang; } 5=\text { nyeri hebat }\end{array}$} \\
\hline
\end{tabular}

Keterbatasan pada program latihan ini terutama diakibatkan oleh adanya komorbiditas. Penyakit otot, sendi, dan saraf merupakan faktor penghambat untuk latihan. Penyakit jantung ataupun paru kronik menurunkan kapasitas fungsional sehingga pasien tidak dapat mencapai tingkatan latihan yang diharapkan. Kurangnya kesediaan pasien untuk menjalani program latihan menyebabkan hasil yang latihan yang tidak sesuai dengan data dari berbagai penelitian. Umumnya ini timbul karena pasien tidak menganggap program latihan ini sebagai suatu terapi, namun hanya sebagai program tambahan (adjuvant), sehingga tidak menimbulkan minat yang tinggi untuk menyelesaikan program. ${ }^{8}$ Sementara program latihan akan lebih efektif jika diimplentasikan jangka panjang. Salah satu metode untuk mengatasinya adalah dengan memberikan program latihan rumah yang terukur dan dimonitor dengan baik, yang memberikan hasil serupa dengan program latihan dibawah supervisi. ${ }^{22}$

\section{SIMPULAN}

Telah dilaporkan kasus seorang laki-laki 58 tahun dengan klaudikasio intermiten pada iskemia tungkai kronik 
yang telah menjalani terapi medikamentosa, revaskularisasi, dan latihan olahraga yang disupervisi. Pasien tersebut menjalani program latihan yang disupervisi, walaupun tidak dapat menjalankan seluruh sesi program latihan, dan masih terlalu dini untuk menilai peningkatan yang dihasilkan. Walaupun begitu, pada program latihan jangka pendek tersebut dapat ditemukan peningkatan, baik dari kemampuan berjalan, nilai $A B I$, maupunjarak berjalan tanpa nyeri.

Latihan olahraga memainkan peranan penting sebagai terapi primer pada pasien dengan penyakit arteri perifer, dengan tujuan meningkatkan kapasitas fungsional dan kualitas hidup, terutama untuk manajemen jangka panjang. Program latihan olahraga, sebagai kombinasi terhadap farmakoterapi optimal dan revaskularisasi, merupakan standar terapi yang direkomendasikan untuk pasienpasien dengan penyakit arteri perifer.

\section{DAFTAR RUJUKAN}

1. Norgren L, Hiatt WR, Dormandy JA, Nehler MR, Harris KA, Fowkes FG, et al. TASC II inter-society consensus for the management of peripheral arterial disease. Eur $\mathrm{J}$ Vasc Endovasc Surg 2007;33(1):S1-75.

2. Hirsch AT, Haskal ZJ, Hertzer NR, Bakal CW, Creager MA, Halperin $\mathrm{JL}$, et al. ACC/AHA 205 practice guidelines for the management of patients with peripheral arterial disease (lower extremity, renal, mesenteric, and abdominal aortic). Circulation 2006;113:e463-e654.

3. Bistok Sihombing, Prevalensi Penyakit Arteri Perifer Pada Populasi Penyakit Diabetes Melitus di Puskesmas Kota Medan, http://repository.usu.ac.id/handle/123456789/ $\underline{6331}$

4. Mardiansyah. Data rekam medis Pusat Jantung Nasional Harapan Kita. Jakarta; 2012.

5. White, C. Intermitten claudication. NEJM 2007;356:1241-1250.
6. Murphy TP, Cutlip DE, Regensteiner JG, Mohler ER, Cohen DJ, Reynolds MR, et al. Supervised exercise versus primary stenting for claudication resulting from aortoiliac peripheral artery disease : six-month outcomes from the claudication: exercise versus endoluminal revascularization (CLEVER) study. Circulation 2012;125:130139.

7. Stewart KJ, Hiatt WR, Regensteiner JG, Hirsch AT. Exercise training for claudication. NEJM 2002;347(24):1941-1950.

8. Tendera $M$, Aboyans $V$, Bartelink $M-L$, Baumgartner I, Clement D, Collet J-P, et al. ESC guidelines on the diagnosis and treatment of peripheral arterial diseases. European Heart Journal 2011; 32(22):28512906.

9. Milani RV, Lavie CJ. The role of exercise training in peripheral arterial disease. Vasc Med 2007;12:351-358.

10. Rooke TW, Hirsch AT, Misra S, Sidawy AN, Beckman JA, Findeiss LK, et al. 2011 ACC/AHA Focused update of the guidelines for the management of patients with peripheral arterial disease (updating the 2005 guideline). Circulation 2011; 124:20202045.

11. Parr BM, Derman EW. The effect of exercise training in patients with peripheral vascular disease-a review. SAJSM 2006;18(4):116121.

12. Watson L, Ellis B, Leng GC. Exercise for intermitten claudication. Cochrane Database Syst Rev 2008;4:1-55.

13. Gardner AW, Poehlman ET. Exercise rehabilitation programs for the treatment of claudication pain: a meta-analysis. JAMA 1995;274:975-80.

14. McDermott MM, Ades P, Guralnik JM, et al: Treadmill exercise and resistance training in patients with peripheral arterial disease with and without intermittent claudication: a randomized controlled trial. JAMA 2009;301:165-170.

15. Spronk S, Bosch JL, Veen HF, Hoed PT, Hunink MGM. Intermitten claudication: functional capacity and quality of life after exercise training or percutaneous transluminal angioplasty-systematic review. RSNA 2005;235:833-842.

16. Spronk S, Bosch JL, Veen HF, Hoed PT, Pattynama PMT, Hunink MGM. Intermitten claudication: effectiveness of endovascular revascularization versus supervised hospital- 
based exercise training-randomized controlled trial. RSNA 2009;250(2):586-595.

17. Hiatt WR, Wolfel EE, Meier $\mathrm{RH}$, Regensteiner JG. Superiority of treadmill walking exercise versus strength training for patients with peripheral arterial disease. Implications for the mechanism of the training response. Circulation 1994;90:18661874.

18. Hamburg NM, Balady GJ. Exercise rehabilitation in peripheral artery disease : functional impact and mechanism of benefits. Circulation 2011; 123:87-97.

19. Stewart KJ, Ratchford EV, Williams MA. Exercise for restoring health and preventing vascular disease. In : Blumenthal RS, Foody JM, Wong ND, editors. Preventive cardiology: a companion to braunwald's heart disease. Philadelphia. Elsevier Saunders;2011:541-551.

20. Whyte JJ, Laughlin $\mathrm{MH}$. The effect of acute and chronic exercise on the vasculature. Acta Physiol 2010;199(4):441-450

21. Bronas UG, Hirshc AT, Murphy T, Badenhop D, Collins TC, Ehrman JK, et al. Design of the multicenter standardized supervised exercise training intervention for the CLEVER study. Vasc Med 2009;14:313-321.

22. Gardner AW, Parker DE, Montgomery PS, Scott KJ, Blevins SM. Efficacy of quantified home-based exercise and supervised exercise in patients with intermitten claudication. Circulation 2011;123:491-498 